\title{
「等価線形化法に基づく応答評価式一エネルギーバランスに基づく考察と 限界変形の超過確率の評価への適用一」に対する討論
}

（岡野 創，宮本裕司著 日本建築学会構造系論文集，第562号，45-52，2002年12月号掲載）

\section{DISCUSSION ON "EQUATIONS DERIVED FROM EQUIVALENT LINEARIZATION METHOD}

Consideration based on energy balance and its application to evaluation of probability of excess of deformation capacity"

(Hajime OKANO and Yuji MIYAMOTO, J. Struct, Constr. Eng., AIJ, No.562, 45-52, Dec., 2002)

秋山宏*

Hiroshi AKIYAMA

Discussed items are summarized as follows.

1 The authors mention to the total energy input very simply. Do authors intend to insist on the ineffectiveness of the total energy input in estimating maximum deformation?

2 Is it theoretically true or simply conventional to consider that the maximum deformation is governed by the instantaneous energy input?

3 The reduction to the one-degree of freedom system does not claim the possibility of the equivalent linearization method but expresses only its limitation in dealing with damage distribution. Is it true or not?

4 The maximum deformation is one of important responses. But, why do the authors adhere to the maximum deformation so strongly on the sacrifice of true understanding of the energy balance?

Keywords : energy balance, total energy input, instantaneous energy input, maximum deformation, damage distribution, equivalent linearization method エネルギーの鈾合，総エネルギー入力，瞬間エネルギー入力，最大変形，損傷分布，等化線形化手法

論点を明らかにする為に岡野創，宮本裕司両氏の標記論文中の 2 简所を引用します。

第 1 箇所, page49，左段 5 行目から「エネルギー法は全継続時 間における総入力エネルギーとのバランスに基づくものと，定常ラ ンダム振動における単位時間あたりのエネルギーバランスに基づく ものに大別される。総入カエネルギーは本来は累積損傷と対応する ものであるが,最近では最大応答変形の推定に適用した研究も多い。 最大忘答変形を求めるには何らかの方法で瞬間的なエネルギーの入 力効率を仮定する必要があり；その多くは収敛計算を必要とする 8)，9!。文献 11）は解を得ているが，地震動の周期特性との関係は 論じられていない。地震動の周期特性との関連を論ずる場合は，建 物の周期あたりの入力エネルギーを明確に論ずる必要があるので、 単位時閒あたりのエネルギーバランスを定義した方が議論が明快に なる。そこで，以下では定常ランダム振動の゙ェネギーバランスに 基づいて考察を進める。」

第 2 箅所, page46 右段 9 行目から,「多層モデルの代表変位 とし自由度系の対応については既に十分論じられており6)、筆者も 確認したことがある゙リの゙，時刻歴応答計算は 1 自由度系で行う。」

第 1 筒所における総エネルギーのバラシスーの言及は, 引用文献 も明らかにされず，何を意図されているのか全く理解できません。 総エネルギー入力の概念の有効性を信ずる者の一人として, 総エネ
ルギー入力に対する粗略な扱いにより，エネルギーの釣合に着目す ることの本質が見失われることを恐れ，ここに討論をお願いする次 第です。

エネルギーの釣合の本質は熱力学の第 1 法則として明確にされて おり，物理的現象は全てこれと矛盾することはありません。従って， 敢えてエネルギーの釣合に言及する場合，それを考慮する必然性が 明確に述べられる必要があります。総エネルギー入力は構造物が受 ける損傷の総量に蕨密に対応し，しかも極めて安定した量です ${ }^{1 *)}$, 2*)。一方, 瞬間的なエネルギー入力と最大変形との蕨密な対応は理 論的には全くありません。

定常ランダム振動では平均的には一定振幅下の振動が扱われ，一 方，最大变形は瞬間的に起こります。また，振動を起こすのはエネ ルギーです。これ等を三段論法的に再構成すると，最大変形は瞬間 的エネルギー入力で惹き起こされると言えます。しかし，これは単 なる形式論理に過ぎません。

無減衰弾性系が自由振動している場合，1サイクル毎にエネルギ 一を供給しなく上も系は最大变形を生じます。また無减衰弾性系の 地震時の最大変形はその生起時刻迄の入力エネルギーの積分值によ って生じます。

免震構造でも，免震層の最大変形は弾性系の場合と同様で，エネ ルギー入力の累積値により惹き起こされ，アインレーターに蓄えら 
れたエネルギーが徐々に移行して, 最終的にダンパーに吸収される 過程で最大変形を生ずると考えるべきです。塑性域においても，例 えば, スリップ型の復元力特性を持つ系では, 正, 負の各荷重領域 において累積塑性変形と最大塑性変形は一致します。従って, 瞬間 的エネルギー入力が最大変形をもたらす様な復元力特性は存在する かも知れませんが，それは極めて稀有な例です。以上から最大変形 に直接関わる瞬間エネルギーを厳密に定義することは無理であり， 瞬間的エネルギー入力は極めて便宜的な概念と云わざるを得ません。 総エネルギー入力は累積塑性変形と直接対応します。また，構造物 の被災後の修復性に関わる残留変形は正, 負の荷重領域における累 積塑性変形の差に強く依存します。累積塑性変形との対応が最も㖟 昧なのが最大変形です。これは累積塑性変形が極めて安定している のに対して, 最大変形は復元力特性, 地動特性等の多くのパラメー ターに依存する不安定な量であることを示しています3*)，4*),5*), 6*)。

更に総エネルギー入力の安定性は，多首骨組における損傷分布の 把握の重要性と表裹一体です。等価線形化法により 1 自由度系への 樎約が可能な場合は，損傷分布が既知の場合のみです。即ち，全損 傷が一筬所に集中する場合と，建物全体に均一に分散する場合のみ です。

一般には損傷分布は多種多様であり，これ等を一般的に扱い得な いことが等価線形化手法の限界です。以上の論点が本論文では極め て曖昧な形で考察されています。討論の論点を以下に要約いたしま す。
1 総エネルギー入力への言及は, 最大変形を求める上での総エネ ルギー入力の無効性を主張しているのですか。

2 瞬間的エネルギー入力を最大変形を支配する量と見なすことは, 理論的に可能でしょうか。それとも単なる便宜的な措膡でしょ 5 か。

31自由度系への縮約は等価線形化手法の可能性を示すものでは なく，一般の損傷分布を报い得ない限界を示すものではないで しょうか。

4 最大変形は重要な応答量の一つです。しかし，エネルギーの验 合の本質を曲げてまで，最大変形に固執する理由は何ですか。

引用文献

$1 *$ ） 加藤勉，秋山宏：強震による粠造物へのエネルキ入力と粠造物の損伤 日本建策学会論文報告集，第 235 号, pp.9-18，1975.9.

$2 *)$ 秋山宏 : 建築物の耐震極限設計第 2 版, 東京大学出版会, 1987

$3 *)$ 秋山宏，大井謙一：混合型の復元力特性をもつせん断型多層骨組の損 侮集中特性，日本建築学会論文報告集，第 303 号, pp.31-38, 1981.5 .

$4 *$ ）秋山宏：第 1 履エネルギ集中型柔㣚混合棬造の地震応答予測，日本建 学会棬造系論文報告集, 第 400 号, pp.77-84, 1989.6.

$5 *$ ）高䨩誠，秋山宏：地震時における多層骨組の最大変形とエネルキー応 答, 日本建築学会構造系論文集, 第 515 号, pp.59-66, 1998.1 .

$6 *$ 秋山宏: エネルキーのの動合に基つく建築物の設計，技報堂出版，1999. (2003年 1 月 7 日原稿受理，2003年 2 月19日採用決定） 